\title{
PRINSIP DAN LANDASAN EKONOMI ISLAM M. QURAISH SHIHAB
}

\author{
Rizki Syahputra \\ Dosen Tetap Sekolah Tinggi Ilmu Ekonomi (STIE) Labuhanbatu
}

M. Quraish Shihab menyatakan bahwa tidak semua persoalan ekonomi dirinci oleh al-Qur'an, karena persoalan ini berkembang dari masa kemasa. Atas dasar itu, al-Qur'an hanya memberi tuntunan umum, berupa prinsip-prinsip dasar yang dapat dijabarkan umat sepanjang masa sesuai dengan kebutuhan, kondisi sosial, dan perkembanangan masyarakat. Dari sinilah lahir prinsip-prinsip yang bukan saja dalam bidang ekonomi, tetapi juga menyangkut segala aspek kehidupan dunia dan akhirat.

\section{Pendahuluan}

Sejarah membuktikan bahwa pemikir muslim merupakan penemu,peletak dasar,dan pengembang dalam berbagai bidang-bidang ilmu. Nama-nama pemikir muslim bertebaran disana-sini menghiasi arena ilmu pengetahuan. Baik ilmu-ilmu alam maupun ilmu-ilmu sosial(Adiwarman A. Karim, 2010, h:8).Saat ini ada dua sistem ekonomi yang dianut oleh umat manusia di dunia, yaitu sistem ekonomi Kapitalis dan sistem ekonomi Sosialis. Sistem ekonomi Kapitalis banyak dianut oleh negara-negara yang berada di belahan Benua Amerika, Eropa Barat, dan beberapa negara di Benua Asia, sedangkan sistem ekonomi Sosialis banyak dianut oleh negara-negara yang berada di belahan Eropa Timur dan beberapa negara Asia.

Namun saat ini masyarakat dunia telah mengalami kejenuhan dengan kedua sistem ekonomi tersebut.Dengan melihat kenyataan tersebut, maka kemudian muncul pemikiran baru yang menawarkan ajaran Islam tentang ekonomi sebagai sebuah sistem ekonomi alternatif. Sistem ekonomi Islam adalah ilmu ekonomi yang dilaksanakan dalam praktek (penerapan ilmu ekonomi) sehari-harinya bagi individu, keluarga, kelompok masyarakat maupun pemerintah/penguasa dalam rangka mengorganisasi faktor produksi, distribusi, dan pemanfaatan barang dan jasa yang dihasilkan tunduk dalam peraturan/perundang-undangan Islam (Sunnatullah)(Suhrawardi K.Lubis,2000, h:1). 
Sistem ekonomi Islam adalah suatu sistem ekonomi yang didasarkan pada ajaran dan nilai-nilai Islam. Sumber dari keseluruhan nilai tersebut sudah tentu Alquran dan Hadist, Ijma' dan Qiyas. Karena didasarkan pada nilai-nilai Ilahiah, sistem ekonomi Islam tentu saja akan berbeda dengan sistem ekonomi kapitalis dan sosialis, Para pemikir ekonomi Islam berbeda pendapat dalam memberikan kategorisasi terhadap prinsip-prinsip ekonomi Islam. Khurshid Ahmad mengkategorisasi prinsip-prinsip ekonomi Islam pada: Prinsip tauhid, rububiyyah, khilafah, dan tazkiyah(Muslimin H. Kara, 2005,h:37-38). Sehubungan dengan itu M. Quraish Shihab(2011, h:197) menyatakan bahwa:

Tidak semua persoalan ekonomi dirinci oleh al-Qur'an, karena persoalan ini berkembang dari masa kemasa. Atas dasar itu, al-Qur'an hanya memberi tuntunan umum, berupa prinsip-prinsip dasar yang dapat dijabarkan umat sepanjang masa sesuai dengan kebutuhan, kondisi sosial, dan perkembanangan masyarakat. Kita dapat menyimpulkan prinsip-prinsip dasar ajaran Islam pada keyakinan tauhid. Dari sinilah lahir prinsip-prinsip yang bukan saja dalam bidang ekonomi, tetapi juga menyangkut segala aspek kehidupan dunia dan akhirat.

Adapun sebabnya penulis memilih tokoh tersebut sebagai berikut: pertama, M. Quraish Shihab merupakan ulama/cendekiawan muslim yang sangat peduli terhadap masalah ekonomi Islam walapun beliau bukan dikenal sebagai ekonom. Kedua, dengan mengungkap pemikiran tokoh tersebut diharapkan dapat memperkaya konsep-konsep ekonomi Islam.

Pemikiran .M.Quraish Shihab dalam bidang ekonomi Islam tersebut tampak sangat dipengaruhi oleh keahliannya dalam bidang tafsir Al-Qur'an yang dipadukan dengan penguasaannya yang mendalam terhadap berbagai ilmu lainnya baik ilmu-ilmu keislaman maupun ilmu pengetahuan umum serta konteks masyarakat Indonesia. Pemikiran dan gagasan .M. Quraish Shihab tersebut telah pula menunjukkan dengan jelas bahwa di dalam Al-Qur'an terdapat ayat-ayat yang memiliki implikasi terhadap munculnya konsep dasar sistem ekonomi Islam yang pada gilirannya dapat menjadi salah satu bidang kajian yang cukup menarik. 


\section{Definisi Ekonomi Islam}

Imamudin Yuliadi (2006, h:6)menginventarisir enam definisi ekonomi Islam sebagai berikut:

1. Ekonomi Islam adalah ilmu dan aplikasi petunjuk dan aturan syariah yang mencegah ketidakadilan dalam memperoleh dan menggunakan sumberdaya material agar memenuhi kebutuhan manusia dan agar dapat menjalankan kewajibannya kepada Allah dan masyarakat.

2. Ekonomi Islam adalah: "Ilmu sosial yang mempelajari masalah-masalah ekonomi masyarakat dalam perspektif nilai-nilai Islam.

3. Ekonomi Islam adalah: "Suatu upaya sistematik untuk memahami masalah ekonomi dan perilaku manusia yang berkaitan dengan masalah itu dari perspektif Islam

4. Ekonomi Islam adalah: "Tanggapan pemikir-pemikir muslim terhadap tantangan ekonomi pada zamannya. Di mana dalam upaya ini mereka dibantu oleh Al-Qur'an dan Sunnah disertai dengan argumentasi dan pengalaman empirik

5. Ekonomi Islam adalah "Suatu upaya memusatkan perhatian pada studi tentang kesejahteraan manusia yang dicapai dengan mengorganisasikan sumberdaya di bumi atas dasar kerjasama dan partisipasi

Namun perlu ditegaskan di sini perbedaan pengertian antara ilmu ekonomi Islam dengan sistem ekonomi Islam. Ilmu ekonomi Islam merupakan suatu kajian yang senantiasa memperhatikan rambu-rambu metodologi ilmiah. Sehingga dalam proses perkembangannya senantiasa mengakomodasikan berbagai aspek dan variabel dalam analisis ekonomi. Ilmu ekonomi Islam dalam batas- batas metodologi ilmiah tidak berbeda dengan ilmu ekonomi pada umumnya yang mengenal pendekatan kuantitatif dan kualitatif. Namun berbeda halnya dengan sistem ekonomi Islam yang merupakan bagian dari kehidupan seorang muslim. Sistem ekonomi Islam merupakan suatu keharusan dalam kehidupan seorang muslim dalam upaya untuk mengimplementasikan ajaran Islam dalam aktivitas ekonomi. Sistem ekonomi Islam merupakan salah satu aspek dalam sistem nilai Islam yang integral dan komprehensif. 


\section{Jurnal Ecobisma Vol 1 No. 12014}

\section{Prinsip ekonomi islam}

Para pemikir ekonomi Islam berbeda pendapat dalam memberikan kategorisasi terhadap prinsip-prinsip ekonomi Islam. Khurshid Ahmad mengkategorisasi prinsip-prinsip ekonomi Islam pada: Prinsip tauhid, rububiyyah, khilafah, dan tazkiyah.Mahmud Muhammad Bablily menetapkanlima prinsip yang berkaitan dengan kegiatan ekonomi dalam Islam, yaitu: al-ukhuwwa (persaudaraan), al-ihsan (berbuat baik), al-nasihah (memberinasihat), al-istiqamah (teguh pendirian), dan al-taqwa (bersikap takwa)(Mahmud Muhammad Bablily, 1990,h:15)

\section{Biografi Singkat M. Quraish Shihab}

Muhammad Quraish Shihab, lahir di Rappang, Sulawesi Selatan, 16 Februari 1944. Ia termasuk ulama dan cendikiawan muslim Indonesia yang dikenal ahli dalam bidang tafsir alQur'an. Ayah Quraish Shihab, Prof. KH Abdrurahman Shihab, seorang ulama dan guru besar dalam bidang tafsir. Abdurrahman Shihab dipandang sebagai salah seorang tokoh pendidik yang memiliki reputasi baik di kalangan masyarakat Sulawesi Selatan. Kontribusinya dalam bidang pendidikan terbukti dari usahanya membina dua perguruan tinggi di Ujungpandang, yaitu Universitas Muslim Indonesia (UMI), sebuah perguruan tinggi swasta terbesar di kawasan Indonesia bagian timur, dan IAIN Alauddin Ujungpandang. Ia juga tercatat sebagai mantan rektor pada kedua perguruan tinggi tersebut: UMI 1959 - 1965 dan IAIN $1972-1977$.

Sebagai putra dari seorang guru besar, Quraish Shihab mendapatkan motivasi awal dan benih kecintaan terhadap bidang studi tafsir dari ayahnya yang sering mengajak anakanaknya duduk bersama. Pada saat-saat seperti inilah sang ayah menyampaikan nasihatnya yang kebanyakan berupa ayat-ayat al-Qur'an. 


\section{Jurnal Ecobisma Vol 1 No. 12014}

Pendidikan formalnya dimulai dari sekolah dasar di Ujungpandang. Setelah itu ia melanjutkan ke sekolah lanjutan tingkat pertama di kota Malang sambil "nyantri" di Pondok Pesantren Darul Hadis al-Falaqiyah di kota yang sama. Untuk mendalami studi keislamannya, Quraish Shihab dikirim oleh ayahnya ke al-Azhar, Cairo, pada tahun 1958 dan diterima di kelas dua sanawiyah. Setelah itu, ia melanjutkan studinya ke Universitas al-Azhar pada Fakultas Ushuluddin, Jurusan Tafsir dan Hadits. Pada tahun 1967 ia meraih gelar LC (setingkat sarjana S1). Dua tahun kemudian (1969), Quraish Shihab berhasil meraih gelar M.A. pada jurusan yang sama dengan tesis berjudul “al-I'jaz at-Tasryri'i al-Qur'an al-Karim (kemukjizatan al-Qur'an al-Karim dari Segi Hukum)”. Pada tahun 1980, Quraish Shihab kembali ke Mesir untuk meneruskan studinya di Program Pascasarjana Fakultas Ushuluddin Jurusan Tafsir Hadis, Universitas Al-Azhar. Hanya dalam waktu dua tahun (1982) dia berhasil menyelesaikan disertasinya yang berjudul "Nazm al-Durar li al-Biqai Tahqiqwa Dirasah" dan berhasil dipertahankan dengan nilai Suma Cum Laude.(Abuddin Nata,2005,h:363-365)

Karya-karya yang ia tulis antara lain berisi kajian di sekitar epistemologi Al-Qur'an hingga menyentuh permasalahan hidup dan kehidupan dalam konteks masyarakat Indonesia kontemporer. Beberapa karya tulis yang telah dihasilkannya antara lain: disertasinya: Durar li al-Biga'i (1982), Membumikan Al-Qur'an: Fungsidan Peran Wahyu dalam Kehidupan Masyarakat (1992), Wawasan Al-Qur'an:Tafsir Maudlu'i atas Berbagai Persoalan Umat (1996), Studi Kritis Tafsir al-Manar (1994), Mu'jizat Al-Qur'an Ditinjau dari Aspek Bahasa (1997), Tafsir al-Mishbah.

M.Quraish Shihab memang bukan satu-satunya pakar al-Qur'an di Indonesia, tetapi kemampuannya menerjemahkan dan meyampaikan pesan-pesan al-Qur'an dalam konteks masa kini dan masa modern membuatnya lebih dikenal dan lebih unggul daripada pakar 


\section{Jurnal Ecobisma Vol 1 No. 12014}

alQur'an lainnya. Dalam hal penafsiran terhadap ayat-ayat al-Qur'an yang berhubungan dengan sabar, ia cenderung menekankan pentingnya penggunaan metode tafsir maudu'i(tematik), yaitu penafsiran dengan cara menghimpun sejumlah ayat al-Qur'an yang tersebar dalam berbagai surah yang membahas masalah yang sama, yaitu tentang sabar kemudian menjelaskan pengertian menyeluruh dari ayat-ayat tersebut dan selanjutnya menarik kesimpulan sebagai jawaban terhadap masalah yang menjadi pokok bahasan. Menurutnya, dengan metode ini dapat diungkapkan pendapat-pendapat al-Qur'an tentang berbagai masalah kehidupan, sekaligus dapat dijadikan bukti bahwa ayat al-Qur'an sejalan dengan perkembangan iptek dan kemajuan peradaban masyarakat.

M. Quraish Shihab banyak menekankan perlunya memahami wahyu Ilahi secara kontekstual dan tidak semata-mata terpaku pada makna tekstual agar pesan-pesan yang terkandung di dalamnya dapat difungsikan dalam kehidupan nyata. Ia juga banyak memotivasi mahasiswanya, khususnya di tingkat pasca sarjana, agar berani menafsirkan alQur'an, tetapi dengan tetap berpegang ketat pada kaidah-kaidah tafsir yang sudah dipandang baku. Menurutnya, penafsiran terhadap al-Qur'an tidak akan pernah berakhir. Dari masa ke masa selalu saja muncul penafsiran baru sejalan dengan perkembangan ilmu dan tuntutan kemajuan. Meski begitu ia tetap mengingatkan perlunya sikap teliti dan ekstra hatihati dalam menafsirkan al-Qur'an sehingga seseorang tidak mudah mengklaim suatu pendapat sebagai pendapat al-Qur'an. Bahkan, menurutnya adalah satu dosa besar bila seseorang mamaksakan pendapatnya atas nama al-Qur'an. 


\section{Pendapat M. Quraish shihab mengenai Prinsip-Prinsip Ekonomi Islam}

Pada buku lainnya M. Quraish Shihab (2011, h:409) menyatakan bahwa secara umum prinsip ekonomi Islam terangkum dalam empat prinsip pokok yaitu tauhid, keseimbangan, kehendak bebas, dan tanggung jawab.

Menurut Quraish Shihab Ekonomi yang secara sederhana dapat dikatakan "perilaku manusia yang berhubungan dengan kegiatan mendapat uang dan membelanjakannya" memperoleh perhatian yang besar dari al-Qur'an dan Sunnah, karena memang hal ini adalah sesuatu yang sangat penting; dalam kehidupan, bahkan dapat mengakibatkan runtuh dan tegaknya kemanusiaannya. Sedemikian pentingnya persoalan ini sehingga al-Qur'an dalam mengajak manusia mempercayai dan mengamalkan tuntunan- tuntunannya dalam segala aspek, sering kali menggunakan istilah-istilah yang dikenal oleh dunia ekonomi dan bisnis; seperti jual beli, untung rugi, kredit, dan sebagainya. Perhatikan, antara lain, firman-Nya:
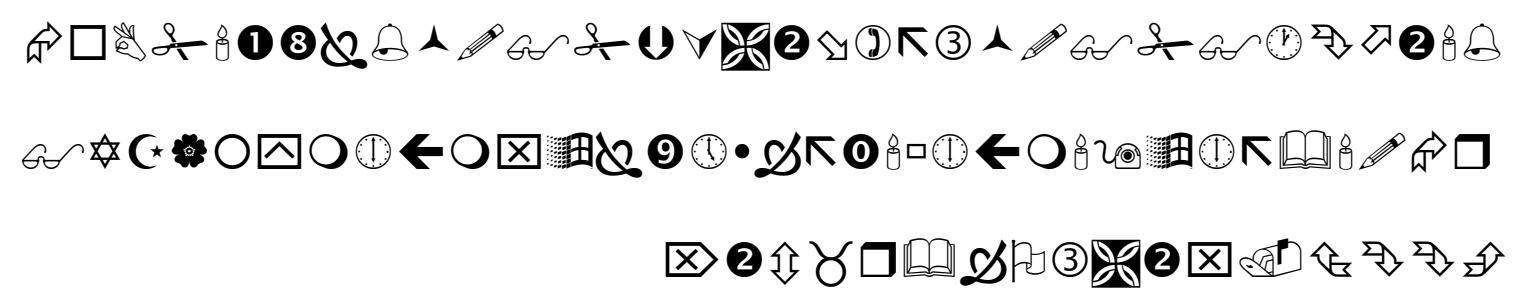

Artinya: Siapakah yang ingin memberi qardh (kredit) kepada Allah dengan kredit Jang baik, maka Allah akan melipatkan gandakan qardh itu) untuknya dan dia akan memperoleh ganjaran yang banyak (QS. al-Hadid [57]: 11).

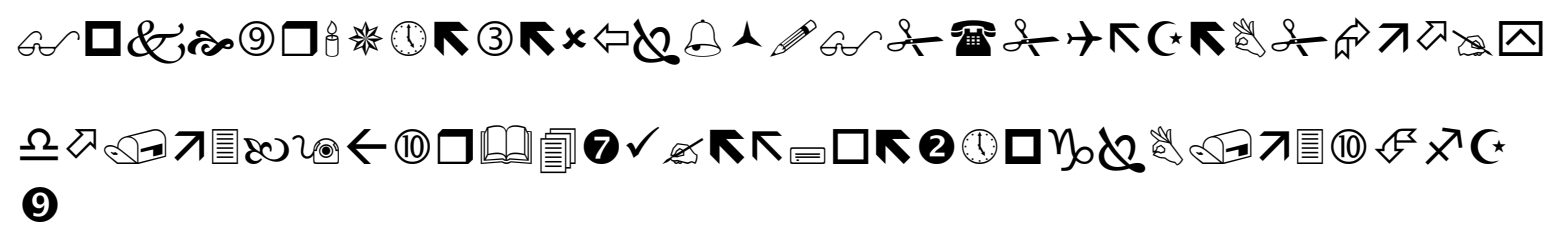




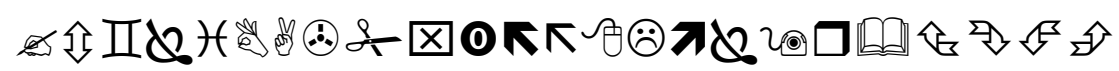

Artinya: Wahai orang-orang yang beriman, sukakah kamu Aku tunjukkan satu perniagaan yang menyelamatkan kamu dari siksa yang pedih? (QS. ash-Shaff [61]: 10).

Imbalan dari perniagaan itu, atau keuntungannya adalah:

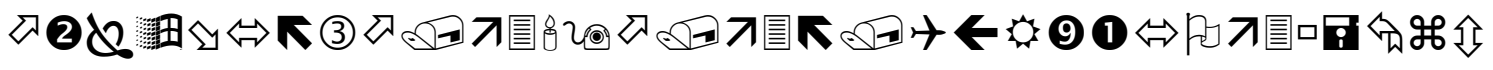 \\ (9) (3) (1)}

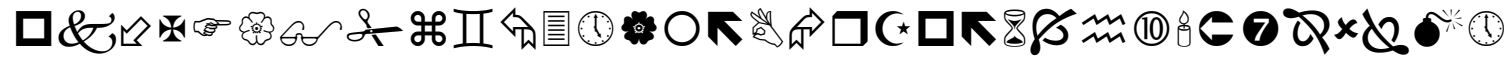

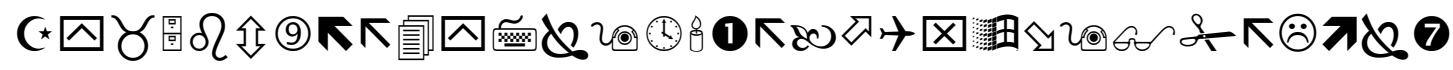 囚}

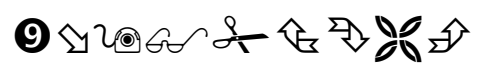

Artinya: Allah mengampuni dosa-dosa kamu dan memasukkan kamu ke dalam surga yang mengalir di bawahnya sungai-sungai dan (memasukkan kamu) ke ke tempat tinggi yang baik di dalam surga 'Adn. Itulah keuntungan yang besar (QS.ash-Shaff [61]: 12)

M. Quraish Shihab menyatakan bahwa tidak semua persoalan ekonomi dirinci oleh al-Qur'an, karena persoalan ini berkembang dari masa kemasa. Atas dasar itu, al-Qur'an hanya memberi tuntunan umum, berupa prinsip-prinsip dasar yang dapat dijabarkan umat sepanjang masa sesuai dengan kebutuhan, kondisi sosial, dan perkembanangan masyarakat. Kita dapat menyimpulkan prinsip-prinsip dasar ajaran Islam pada keyakinan tauhid. Dari sinilah lahir prinsip-prinsip yang bukan saja dalam bidang ekonomi, tetapi juga menyangkut segala aspek kehidupan dunia dan akhirat.

Kita dapat menyirnpulkan prinsip dasar ajaran Islam pada keyakinan Tauhid. Dari sinilah lahir prinsip-prinsip yang bukan saja dalam bidang ekonomi, tetapi juga menyangkut 


\section{Jurnal Ecobisma Vol 1 No. 12014}

segala aspek kehidupan dunia dan akhirat. Tauhid dapat diibaratkan dengan matahari. Kalau di alam raya ini ada matahari yang diciptakan Allah menjadi sumber kehidupan makhluk di permukaan bumi ini dan yang berkeliling di sekitarnya planet-planet tata surya lagi tidak dapat melepaskan diri darinya, maka demikian juga dengan Tauhid. Di sekelilingnya ada kesatuan-kesatuan yang tidak boleh dilepaskan darinya, seperti kesatuan kemanusiaan, kesatuan alam raya, kesatuan dunia dan akhirat, kesatuan hukum, dengan keadilan dan kemaslahatan, dan lain-lain.

Menurut Quraish Shihab kesatuan kemanusiaan mengantar pengusaha Muslim menghindari segala bentuk eksploitasi terhadap sesama manusia, Muslim atau non-Muslim. Dari sini dapat dimengerti mengapa Islam mengharamkan bukan saja riba, tetapi juga penipuan atau dugaan dapat mengakibatkan penipuan walau terselubung, seperti larangan memperjualbelikan sesuatu yang tidak/belum jelas sifat dan keadaannya (Ba'ial-Gharar), sebagaimana melarang pula menawarkan barang pada saatkonsumen menerima tawaran yang sama dari orang lain. Kesatuan kemanusiaan mengharuskan manusia berpikir dan mempertimbangkan kepentingan umat manusia dalam semua tindakannya, bukan hanya untuk generasinya, tetapi juga generasi mendatang, sehingga dengan demikian terhindar penggunaan dan pemanfaatan sumber daya alam untuk digunakan secara berlebihan oleh generasi masa kini saja.

Tauhid juga melahirkan keyakinan bahwa segala sesuatu bersumber dari Allah dan berkesudahan kepada-Nya. Dialah Pemilik mutlak dan tunggal, yang dalam genggaman-Nya segala sesuatu, termasuk kepemilikan harta dan kewenangan menetapkan aturan pengelolaan dan pengembangannya. Dan karena Allah Maha Adil dan selalu memperhatikan 


\section{Jurnal Ecobisma Vol 1 No. 12014}

kemaslahatan umat manusia, maka semua ketetapan hukum-Nya, atau produk ijtihad manusia yang dikaitkan dengan nama-Nya, tentulah harus bercirikan keadilan dan kemaslahatan. Di sini lahir ungkapan: "Di mana ada kemaslahatan di sanalah terdapat hukum Allah."

Ada tiga kemungkinan bagi seorang pemilik harta untuk menggunakan hartanya.1). Dibelanjakan, 2) Diinvestasikan, dan 3) Ditumpuk. Ketiga hal ini, jika menimbulkan kerusakan akhlak, dilarang keras oleh al-Qur'an

Menurut Quraish Shihab seseorang boleh membelanjakan hartanya asal tidak mengakibatkan pemborosan atau membuang-buangnya. Seseorang tidak dibenarkan menggunakan hartanya untuk hal-hal yang tidak bermanfaat, apalagi yang sejak awal telah diharamkan, seperti berjudi, berzina, dan minum minuman keras, bahkan seseorang yang terbiasa memberi Bantuan bukan pada tempatnya dapat dikenakan pembatasan kewenangan menggunakan hartanya. Ini adalah salah satu kandungan pesan QS. an-Nisa' [4]: 5.

Menginvestasikan harta pun tidak boleh terlepas dari aspek kemaslahatan dan keadilan itu. Dari sini lahir larangan riba. Apa pun definisi kita tentang riba, yang jelas unsur utamanya-adalah kezaliman, yakni eksploitasi yang lemah oleh yang kuat.

Sedangkan penumpukan tanpa melaksanakan fungsi sosialnya diancam dengan siksa neraka (QS; at-Taubah [9]: 34, al-Humazah [104]: 1-2). Harta harus difungsikan, karena kalau ditumpuk dan tidak difungsikan maka jumlah m.odal kerja yang mestinya tersedia menjadi berkurang, dan ini dapat mengurangi kesejahteraan yang didambakan al-Qur'an. Semua kekayaan yang dimiliki seseorang harus digunakan untuk memenuhi kebutuhan pemilik dan keluarganya, sedang yang berlebih harus diupayakan sedemikian rupa sehingga terjadi sirkulasi harta yang dapat menyentuh masyarakat banyak. Dari sini pula pemusatan 


\section{Jurnal Ecobisma Vol 1 No. 12014}

kekayaan. pada satu atau dua kelompok Orang kaya saja sama sekali terlarang, "Agar harta tidak hanya beredar di antara orang-orang kaya saja di antara kamu" (QS. al-Hasyr [59]: 7).

Menurut Quraish Shihab dari Tauhid lahir juga keyakinan dan keharusan adanya

keseimbangan. Allah menciptakan segala sesuatu dalam keseimbangan "Engkau tidak melihat pada ciptaan ar-Rahman sedikit ketidakseimbangan pun" (QS. al-Mulk [67]: 3). Ketentuan-ketentuaan-Nya serta peraturan dan pengaturan yang direstui-Nya harus selalu berdasar keseimbangan itu sesuai pesan-Nya: "Dan Allah telah meninggikan langit dan Dia meletakkan neraca (keadilan). Supaya kamu jangan melampaui batas neraca itu.

Dari keyakinan Tauhid lahir juga prinsip kebebasan manusia. Allah Yang Memiliki kebebasan mutlak, menganugerahkan kepada manusia kehendak bebas untuk memilih jalan yang hendak ditempuhnya. Manusia yang baik di sisi-Nya adalah yang menggunakan kebebasan itu dalam rangka penerapan nilai Tauhid. Dari sini lahir prinsip tanggung jawab, baik secara individu (fardhu 'ain) maupun kolektif (fardhu kifayah).

\section{Landasan Ekonomi Islam}

Menurut Quraish Shihab Rasul SAW, pernah bersabda: "Aku tidak diutus kecuali untuk menyempurnakan akhlak. Akhlak yang dimaksud mencakup hubungan antara manusia dengan Allah, dengan sesama manusia, alam semesta, serta dengan din sendiri.

Menurut Quraish Shihab di samping itu Rasul SAW memberi sekian banyak petunjuk guna mendukung terciptanya keharmonisan itu. Yang pertama dan utama adalah kejujuran. Dalam konteks ini beliau bersabda: "Tidak dibenarkan seorang Muslim menjual satu jualan yang mempunyai aib kecuali dia menjelaskan aibnya" (HR. al-Quzwaini) Keramahtamahan dan penawaran yang jujur tidak bertele-tele, juga merupakan pesan beliau: "Allah merahmati 


\section{Jurnal Ecobisma Vol 1 No. 12014}

seseorang yang ramah dan toleran dalam menjual, membeli, dan menagih" (HR. Bukhari dan at-Tirmidzi). Di sisi lain beliau melarang an-najsy, yaitu mengajak orang lain untuk menawar padahal yang bersangkutantidak bermaksud membeli, hanya agar orang lain mengikuti dalam tawarannya (HR. Bukhari). Dan masih bertebaran tuntunan lainnya, yang kesemuanya bertujuan melahirkan hubungan harmonis karena memang yang dituntut oleh alQur'an dalam berbisnis adalah 'an taradh(in) (QS. an-Nisa' [4]: 29), yakni berdasar suka sama suka dan kepuasan kedua pihak.

Tetapi perlu diingat bahwa penekanan pada landasan moral ini, sama sekali tidak berarti menolak perolehan keuntungan material, atau tidak memperhitungkan manfaat ekonomi. Keberhasilan ekonomi dalam pandangan Islam

Menurut Quraish Shihab dalam upaya mewujudkan dan memelihara sistem ekonomi yang dikehendaki-Nya, maka al-Qur'an dan Sunnah memberi tuntunan kepada manusia, termasuk pelaku ekonomi. Dalam konteks ini di samping menegaskan bahwa Allah bersama manusia terlibat dalam perolehan rezeki, juga menegaskan bahwa Dia adalah Penjamin rezeki. 'Tidak ada satu binatang melatapun dipermukaan bumi ini, kecuali Allah menjamin rejeki-Nya" (QS. Hud [11]: 6). Di tempat lain ditegaskan-Nya kepada kaum yang tidak menganut ajaran Tauhid bahwa: "Sesungguhnya yang kamu sembah selain Allah tidak mampu memberikan rezeki kepada kamu; maka mintalah rezeki itu di sisi Allah, dan sembahlah Dia dan bersyukurlah kepada-Nya" (QS. al-Ankabut [29]: 17).

Jaminan rezeki yang diberikan Allah itu, tujuannya adalah untuk menanamkan rasa percaya diri, mengembangkan cinta kasih, serta ketenangan batin bila rezeki yang diharapkan belum kunjung tiba. Dengan demikian manusia tidak panik, apalagi berputus asa kalau ,tidak 
berhasil, dan tidak juga angkuh atau lupa daratan serta melupakan-Nya jika berhasil. Jaminan rezeki itu memberinya optimisme untuk terus berusaha walau berkali-kali didera kegagalan.

Menurut Quraish Shihab perlu juga disadari bahwa al-Qur'an tidak memberi rincian menyangkut semua persoalan ekonomi. Prinsip dan nilai-nilai dasarnya antara lain yang disebut di atas dapat dijabarkan oleh manusia sesuai dengan situasi dan perkembangan masyarakatnya. Selama nilai-nilai, yang antara lain disebut di atas telah diperhatikan, maka itu telah dapat dinilai mencerminkan ajaran al-Qur'an dan Sunnah. "Dia sekali-kali tidak menjadikan untuk kamu dalam agama suatu kesempitan pun" (QS. al-Haji [22]: 78). "Allah menghendaki buat kamu kemudahan dan Dia tidak menghendaki buat kamu kesulitan" (QS. al-Baqarah [2]: 185).

Kesimpulan

Secara kategoris sistem ekonomi yang beroperasi dalam aktivitas ekonomi sekarang adalah sistem ekonomi kapitalis, sistem ekonomi sosialis dan sistem ekonomi Islam. Karakteristik sistem ekonomi Islam berbeda dengan sistem kapitalis maupun sosialis. Perbedaannya tidak hanya dalam aspek normatif tetapi juga pada aspek teknis operasionalnya

Dari paparan yang sudah dibahas maka dapat di simpulkan pandangan M. Quraish Shihab tentang prinsip-prinsip ekonomi Islam yaitu:

1. Tauhid

2. Keseimbangan

3. kehendak bebas

4. dan tanggung jawab 


\section{Jurnal Ecobisma Vol 1 No. 12014}

kemudian M. Quraish Shihab juga menjelaskan landasan utama dari ekonomi Islam itu adalah akhlak, seperti kejujuran, ramah-tamah dan lain-lain. Dan M. Quraish Shihab juga mejelaskan mengenai model untuk menciptakan karaktek pelaku ekonomi yang handal dengan menegaskan bahwa Allah bersama manusia terlibat dalam perolehan rezeki, juga menegaskan bahwa Dia adalah Penjamin rezeki dan perlu juga disadari bahwa al-Qur'an tidak memberi rincian menyangkut semua persoalan ekonomi. Prinsip dan nilai-nilai dasarnya antara lain yang disebut di atas dapat dijabarkan oleh manusia sesuai dengan situasi dan perkembangan masyarakatnya.

\section{DAFTAR PUSTAKA}

Antonio, Muhammad Syafii,2001,Bank Syariah dari Teori dan Praktek, Gema Insani Press,Jakarta

Bablily, Mahmud Muhammad,1990,Etika Bisnis: Studi Kajian KonsepPerekonomian Menurut al-

Qur'an dan as-Sunnah, terj. Rosihin A. Ghani, Ramadhani, Solo

Hidayat, Mohammad, 2010 An Introduction to the Sharia Economic, Zikrul Hakim, Jakarta

Kara, Muslimin H, 2005,Bank Syariah Di Indonesia Analisis Terhadap Pemerintah IndonesiaTerhadap Perbankan Syariah, UII Press, Yogyakarta

Karim, Adiwarman A.,2010,Ekonomi Mikro Islami, Rajawali Press,Jakarta

Lubis, Suhrawardi K.,2000 Hukum Ekonomi Islam, Sinar Grafika, Jakarta

Nata, Abuddin,2005 Tokoh-Tokoh Pembaharuan Pendidikaan Islam di Indonesia, Raja Grafindo Persada, Jakarta

Shihab, M. Quraish,2011 Menabur Pesan Ilahi: Al-Qur'an dan Dinamika KehidupanMasyarakat, Lentera Hati, Jakarta

Shihab, M. Quraish, Wawasan al-Qur'an, Bandung: Mizan, 2011 